\title{
Relevance of SARS-CoV-2 in food safety and food hygiene: potential preventive measures, suggestions and nanotechnological approaches
}

\author{
Zafer Ceylan' $^{1}$ (D) Raciye Meral $^{2}$ (D) Turgay Cetinkaya $^{3,4}$ (D)
}

Received: 4 May 2020/Accepted: 3 June 2020/Published online: 11 June 2020

(C) Indian Virological Society 2020

\begin{abstract}
Severe acute respiratory syndrome coronavirus 2 (SARS-CoV-2) is easily transmitted from person to person, which has fueled the ongoing pandemic. Governments in different countries have taken drastic actions such as complete lockdown. However, little attention has been paid to food safety and its potential linkage with the coronavirus disease (COVID-19) pandemic. SARS-CoV-2 spread from staff to food products or food surfaces is conceivable. At least, instead of consuming unpackaged or uncovered foods, consumption of boiled or canned foods processed at high temperatures should be preferred. Before consumption, consumers should clean the surface of canned foods. In addition to recommending or enforcing simple precautions, such as using masks, governments must conduct mandatory SARS-CoV-2 tests regularly and intermittently for personnel who handle food materials or supporting materials (e.g., plastic pouches). Local markets, such as those in Wuhan, which sell live animals and exotic foods for consumption, are a concern. Trade of exotic or wild animals, unhygienic marketplace conditions, and not cooking at high temperatures ought to be prohibited. The consumption of vitamins, minerals, and other food-derived
\end{abstract}

Turgay Cetinkaya

turgay.cetinkaya@yalova.edu.tr

1 Department of Seafood Processing Technology, Faculty of Fisheries, Van Yüzüncü Yıl University, 65080 Van, Turkey

2 Department of Food Engineering, Faculty of Engineering, Van Yüzüncü Yıl University, 65080 Van, Turkey

3 Food Processing Department, Armutlu Vocational School, Yalova University, 77500 Yalova, Turkey

4 Department of Food Engineering, Graduate School of Science and Engineering and Technology, Istanbul Technical University, 34467 Istanbul, Turkey compounds such as omega fatty acids is a prudent way to improve the performance of the immune system. In addition, nano-encapsulated materials with controlled release properties may be useful in protecting food products and packaging from SARS-CoV-2 contamination.

Keywords SARS-CoV-2 $\cdot$ COVID-19 $\cdot$ Foodborne viruses · Food safety $\cdot$ Food hygiene $\cdot$ Nanotechnology

\section{Introduction}

Humans have for millennia faced many health problems caused by bacterial or viral infections. In particular, bacteria are a major cause of foodborne illnesses. Therefore, studies on foodborne illnesses have focused on bacterial spoilage in food and foodborne pathogens, with comparatively less attention given to viruses. Generally, a virus is defined as an infectious agent that is typically $20-300 \mathrm{~nm}$ in size, contains RNA or DNA, and requires a living host cell for its replication. The collective host range of viruses is broad and includes animals, humans, plants, and bacteria [26]. Serious diseases caused by viruses include Ebola, acquired immunodeficiency syndrome, and avian influenza. The latter two occur globally. Coronaviruses (CoVs) are members of the subfamily Orthocoronavirinae in the family Coronaviridae. Illnesses caused by CoVs include the common cold (caused by $\mathrm{HCoV}-229 \mathrm{E}$ and $\mathrm{HCoV}-\mathrm{OC} 43$ ), middle east respiratory syndrome (caused by MERS-CoV), severe acute respiratory syndrome (caused by SARS-CoV), and COVID-19, which is caused by SARS-CoV-2 [7, 59]. The latter is the cause of an ongoing pandemic.

The name $\mathrm{CoV}$ is derived from the Latin word corona, meaning "crown" or "halo" which refers to the characteristic appearance of the virus particles viewed by electron 
microscopy. $\mathrm{CoV}$ is zoonotic, meaning it may pass from animals to humans. This typically occurs when infected animals are slaughtered for consumption. [8, 52, 63]. CoV has been identified in bats, cattle, cats, rats, chickens, turkeys, swine, dogs, rabbits, horses and may cause respiratory tract and gastrointestinal diseases $[11,21,33,37,38,48]$. SARS-CoV-2 is a new strain positive-stranded RNA virus covered by a lipid bilayer. The genome identity of SARS-CoV-2 and SARS-CoV exceeded $70 \%$. Angiotensin-converting enzyme 2 is a cell surface protein that SARS-CoV-2 and SARS-CoV can bind with $[45,65]$. The common symptoms of SARS-CoV-2 and SARS-CoV infections are usually pneumonia and fever. However, SARS-CoV-2 has a longer incubation period and is more infectious [45]. SARS-CoV-2, SARS-CoV, and MERS-CoV infections have all been associated with the consumption and trade of wild animals [17, 28, 30, 43, 63]. The ongoing COVID-19 pandemic originated primarily in Wuhan, Hubei Province, China [23, 55]. With regard to food consumption and COVID-19, many initial infections were linked to Wuhan's Huanan Seafood Wholesale market $[6,8,22,23,28]$, which was closed on 01 January 2020. Whether the market is the actual source of the illness is unclear. In another opinion, the market might have boosted the circulation of the virus more rapidly rather than being the source of the virus [62]. As the outbreak increased in scope and attained pandemic status, information about the virus was disseminated through various organizations. For example, the United States Food and Drug Administration (FDA) released some Frequently Asked Questions related to COVID-19 on its website on 13 March 2020 [13]. Of relevance to this paper, the potential relationship between COVID-19 and food products has received great attention. Some of the examples of questions are: Is food imported to the United States from China and other countries affected by COVID-19 at risk of spreading COVID-19?. Are food products produced in the USA a risk for the spread of COVID-19?. Can COVID-19 be spread by touching SARS-CoV-2-contaminated food, food packaging, or surfaces in contact with food that contact surfaces? Can SARS-CoV-2 be spread via food that has been handled by someone infected with the virus? Should food facilities (grocery stores, manufacturing facilities, restaurants, etc.) undergo special cleaning or sanitation procedures for SARS-CoV-2?. These questions clearly reveal public worry and anxiety about COVID-19. The responses by the FDA indicate a lack of evidence and reported cases for some of the issues. However, some information is known that can increase consumer awareness.

The main aim of this review is to highlight the potential transmission risk of infection SARS-CoV-2 from food products. The audience includes those with the authority to enact legislation to safeguard food quality and consumers.

\section{Relationship between foods and viruses}

Food products play a key role in virus transmission. Viruses may contaminate a wide variety of food products and may remain infective in foods for up to 4 weeks [44]. Norovirus (NoV) and hepatitis A virus (HAV) are two common viruses transmitted by foods [27, 49]. Rotavirus, enterovirus, sapovirus, astrovirus, adenovirus, and hepatitis E virus (HEV) can easily be transmitted to humans via infected food or water [2]. The main foodborne viruses and some of the transmitted food products are summarized in Table 1.

Food contamination can occur in three main ways. The first is during the production process. This can involve contamination of the water in which shellfish grow or contamination of the water used to wash fruits after harvest. The second involves infected food handlers who have not observed good hand hygiene practices, such as hand washing [27]. There are a wide variety of foodborne illnesses associated with viral infections, of which NoV, HAV, and HEV are noteworthy. NoVs have a diameter of 23-40 nm. They belong to the family Caliciviridae. Almost $40 \%$ of the cases of NoV infections are assumed to result from consumption of contaminated food. Shellfish, berry fruits, and green vegetables are major sources of $\mathrm{NoV}$ infection. HAV belongs to the genus Hepatovirus within the family Picornaviridae. HAV can be maintained on food and in water for a long time. Oysters, clams, mussels, lettuce, green onions, raspberries, and strawberries are susceptible to contamination. HEV (which is $35 \mathrm{~nm}$ in diameter) is classified into the unassigned genus Hepevirus. Consumption of pork pies, wild boar, undercooked deer, raw pork, home-made sausages, unpasteurized milk, and shellfish pose a risk of HEV infection [49]. The third contamination way is the consumption of animal-based products that contain a zoonotic virus [49]. Ebola is one of the animal-based virus and discovered in 1976 in Africa. Nipah virus is another animal-borne virus that can cause illness in humans [54]. SARS-CoV and MERS-CoV, members of the CoV family, can be also passed from bats [10]. As summarized in Table 2, studies have identified different animals as intermediate hosts of these viruses.

\section{Potential relationship between SARS-CoV-2 and food products}

There is currently no scientific evidence to indicate a concern with food products related to SARS-CoV-2, according to the FDA. However, consumption of meat or organs of infected animals can result in zoonotic foodborne infections $[9,49]$. China has both a huge population and a 
Table 1 Main foodborne viruses

\begin{tabular}{lll}
\hline Virus name/illness & Possible contamination source & Transmitted food product \\
\hline Hepatovirus A/Hepatit A & Water, human stool & Deli meat, raw beef, shellfish, fruit and vegetable \\
Orthohepevirus A/Hepatitis E & Pig liver & Pork \\
Noravirus/Gastroenteritis & Contaminated water, food, contact surfaces, human stool & Berry fruit, deli meat, shellfish, oyster \\
\hline
\end{tabular}

Velebit et al. [49, 50]

Table 2 Comparison of five zoonotic viruses

\begin{tabular}{|c|c|c|c|c|c|c|}
\hline Virus name & $\begin{array}{l}\text { Identification } \\
\text { year }\end{array}$ & $\begin{array}{l}\text { Number of countries/ } \\
\text { territories }\end{array}$ & Outbreak region/country & $\begin{array}{l}\text { Possible primary/intermediate } \\
\text { hosts }\end{array}$ & Cases & Deaths \\
\hline Ebola & 1976 & 9 & Nzara/Sudan & Fruit Bats/- & 33,577 & 13,562 \\
\hline Nipah & 1998 & 2 & Sungai Nipah/Malaysia & Bats/pigs & 513 & 398 \\
\hline SARS-CoV & 2002 & 29 & Guangdong/China & Bats/civet cat & 8096 & 774 \\
\hline $\begin{array}{l}\text { MERS- } \\
\text { CoV }\end{array}$ & 2012 & 28 & $\begin{array}{l}\text { Arabian Peninsula/Saudi } \\
\text { Arabia }\end{array}$ & Bats/dromedary camels & 2494 & 858 \\
\hline $\begin{array}{l}\text { SARS- } \\
\text { CoV-2* }\end{array}$ & 2019 & 213 & Wuhan/China & $\begin{array}{l}\text { Bats/pig, civets, } \\
\text { pangolins, chicken, seafood }\end{array}$ & $5,502,610$ & 346,761 \\
\hline
\end{tabular}

World Health Organization [57, 58]

*Accessed Date: 25.05 .2020

history of the consumption of wild or exotic animals [23]. In Chinese food culture, live and slaughtered wild animals are considered to be more nutritious [11,35]. Live and dead chickens, pheasants, bats, marmots, deer, dogs, pigs, civets, and organs of rabbits are also sold along with wild animals in food markets [28]. When people keep live and dead animals in close proximity, contact or cross-contamination can easily lead to the spread of the virus. Furthermore, it has been suggested that the transmission of SARS$\mathrm{CoV}-2$ to humans may have been promoted by unhygienic conditions, such as unclean seafood tanks, body fluids of live and dead animals, or insufficient air quality conditions [39].

\section{Precautions and suggestions}

\section{Elimination the potential SARS-CoV-2 risk in food}

One of the most important issues to address for consumers who are concerned with the food risk posed by SARSCoV-2 is the possibility that food products or food packaging can be contaminated by the virus. Foodborne transmission of SARS-CoV-2 needs to be studied [11, 38]. Studies on other viruses have revealed their survival on the surfaces of food products or on surfaces that have been in contact with contaminated food [3,24]. This possibility should also be considered for SARS-CoV-2. Already EU Commission has been highlighted that use of packaging material contaminated by the staff may increase the risk for the consumers in this pandemic term [12]. Food products prepared from exotic or wild animals should be periodically checked. In particular, animals consumed in undeveloped countries should be tested to eliminate the rapid global spread of SARS-CoV-2. Testing of consumers of these products is prudent, as is the testing of wild or exotic animals consumed widely in suburban or city centers. In addition to the FDA suggestions (clean, separate, cook, and chill), at least in times when the chance of infection is greater, canned or packaged foods could be preferred instead of foods that are not canned or packaged. When the latter are purchased, fruits should be washed and stored in water containing lemon juice and vinegar that decrease the $\mathrm{pH}$ value of water $[12,60]$. If possible, during an ongoing epidemic or pandemic, products that are not canned or packaged should be boiled, or boiled food products should be consumed. Wang et al. [51] indicated that high humidity and high temperature can reduce the transmission of SARS-CoV-2. Therefore, the risk of contamination of food products by SARS-CoV-2 may decrease when the midpoint temperature of food products increases. Food products that are packaged or canned could be considered safer. Even so, especially canned materials should be washed well using boiled water. In addition, fresh food products that are chilled should be well cooked after purchase $\left(>100{ }^{\circ} \mathrm{C}\right)$ to eliminate the potential risk of contracting infection, and the midpoint temperature of the products must be checked before being consumed. 


\section{Staff hygiene}

There is definite concern about food industry workers, who should be tested for SARS-CoV-2 to eliminate the potential risk of contamination of food products. In food processing settings, including settings where food is only slightly processed, infected workers may contaminate food products. In addition, worker-to-worker transmission is a risk in settings where personnel are in close contact with each other. A prudent strategy can be for healthy food industry personnel to wear a mask whenever there is a SARS-CoV-2 risk worldwide [12, 60].

Regular hand washing is crucial [12]. Similar viruses are spread via droplets when an infected person coughs or sneezes [1]. SARS-CoV-2 is also disseminated by coughing, sneezing, breathing, and perhaps even by inhaling the virions $[12,56,60]$. Importantly, avoiding touching the face with hands and avoiding close contact with people may be important to lessen the risk of potential SARSCoV-2 contamination in the food industry [8, 60]. On 10 February 2020, the WHO released some prevention guidelines on their website [56]. These societal guidelines-frequent hand washing using soap and water or alcohol-based disinfectants, maintaining social distancing, and avoiding hand contact with the eye, nose, and mouthare applicable to the food industry. In addition to these practices, mobility of food industry personnel such as air travel should be controlled. Regularly (at intervals of at least 14 days), personnel involved in the light preservation of food should be tested for SARS-CoV-2. Personnel who handle packaging that is destined to be used as food containers should also be tested $[12,60]$.

\section{Nutritional suggestions}

Diverse vitamins are important for the immune system. Vitamin A deficiency may impair the immune response [64]. According to one study, patients with chronic diseases, including hypertension, diabetes, coronary heart disease, and tumor-related diseases, are more susceptible to SARS-CoV-2 infection and can have a significantly higher risk of a poor prognosis. This is because these patients can have a less potent immune response [29]. Lack of B vitamins may weaken the immune system. Thus, supplementation with vitamins with the goal of strengthening the immune system is prudent for virus-infected patients. Vitamin B supplementation for patients infected with SARS-CoV-2 might be an option to consider [40]]. Vitamin $\mathrm{C}$ also supports immune functions and may protect against infections caused by CoVs $[19,20,41]$. SARSCoV-2 may cause lower respiratory tract infection, and supplementation with a moderate amount of vitamin $\mathrm{C}$ might be protective [53]. Treatment that includes administration of excess vitamin $\mathrm{C}$ is being performed at hospitals in New York City, which has been especially affected by the COVID-19 pandemic [34]. Decreased vitamin $\mathrm{D}$ and vitamin $\mathrm{E}$ levels in adult cattle and calves have also been associated with bovine $\mathrm{CoV}$ infection $[15,36]$. SARS-CoV and SARS-CoV-2 are both more common in winter when vitamin D status is low in humans $[16,31,61,66]$. In this respect, increased consumption of fatty fish species in the winter season may help strengthen the immune system. Proper supplementation with vitamin $\mathrm{D}$ and vitamin $\mathrm{E}$ may also enhance resistance to SARSCoV-2 [53]. These collective data highlights the important role of vitamins in increasing immune system resistance to $\mathrm{CoV}$ infections. Oxidative stress resulting from selenium deficiency can alter the viral genome. Viruses mutate rapidly to survive the oxidative stress that causes inflammation [18]. The combination of pyrithione and zinc at low concentrations might inhibit the replication of SARS-CoV [47]. Shimizu et al. [42] reported that flavonoids from Pterogyne nitens can inhibit hepatitis $\mathrm{C}$ virus. Jo et al. [25] reported the anti-CoV activity of the flavonoids herbacetin, rhoifolin, and pectolinarin, due to the inhibition of 3C-like protease. These findings suggest that until the role of nutrition in SARS-CoV-2 infections is definitively established, the foregoing observations indicate the wisdom of supplementation with vitamins, minerals, and other important compounds [64]. Furthermore, Galanakis [14] has been noted that there is relationship between the human immune system and intake of bioactive component by human diet.

\section{Novel approaches}

Nanotechnology applications have received a great deal of attention worldwide. Food safety studies have explored the use of nanofibers [5], nanoparticles [4], nanoemulsions [32], and nanoencapsulated materials [46]. Compared to micro- and macro-sized materials, nanosized materials can come into contact with a larger surface area of materials, such as food products. The average diameter of the nanoscale materials ranges from 60 to $600 \mathrm{~nm}$. It is conceivable (although unproven) that nanoscale materials with a controlled release profile could be useful in preventing SARS-CoV-2 contamination of food products and packaging materials. In this regard, nanoscale materials might have a larger contact area on the $300 \mathrm{~nm}$ diameter virus.

\section{Concluding remarks}

The potential linkage between SARS-CoV-2 infection and food safety is an important issue for governments worldwide to consider. During times when the risk of infection is 
higher, such as during the ongoing pandemic, consumption of boiled or canned foods processed at high temperatures is prudent in addition to following general hygiene rules. Governments should mandate the testing of food industry personnel for SARS-CoV-2. The consumption of exotic or wild animal based food products in countries with large populations, such as China, should be avoided to lessen the chance of a new outbreak. Supplementation of diets with vitamins, minerals, and other compounds can increase immunity and reduce the chances of contracting the infection. Novel approaches in the food industry should be applied instead of conventional practices. In this regard, nanofibers, nanoparticles, and nanoencapsulated bioactive materials could be utilized to bolster food safety. Depending on the release time of the payload from nanosized materials, food packaging can be labeled to provide information to the consumers. The COVID-19 outbreak has spread worldwide, but precautions related to the food industry must be taken at the international level. The outcomes of these precautions should be disseminated globally.

\section{Compliance with ethical standards}

Conflict of interest The authors declare there is no conflict of interest.

\section{References}

1. Bai Y, Yao L, Wei T, Tian F, Jin DY, Chen L, Wang M. Presumed asymptomatic carrier transmission of COVID-19. JAMA. 2020. https://doi.org/10.1001/jama.2020.2565.

2. Bosch A, Gkogka E, Le Guyader FS, Loisy-Hamon F, Lee A, van Lieshout L, et al. Foodborne viruses: detection, risk assessment, and control options in food processing. Int $\mathrm{J}$ Food Microbiol. 2018. https://doi.org/10.1016/j.ijfoodmicro.2018.06.001.

3. Butot S, Putallaz T, Sanchez G. Procedure for rapid concentration and detection of enteric viruses from berries and vegetables. Appl Environ Microbiol. 2007. https://doi.org/10.1128/AEM.0124806.

4. Ceylan Z. Use of characterized chitosan nanoparticles integrated in poly (vinyl alcohol) nanofibers as an alternative nanoscale material for fish balls. J Food Saf. 2018. https://doi.org/10.1111/ jfs. 12551 .

5. Ceylan Z, Meral R, Karakaş CY, Dertli E, Yilmaz MT. A novel strategy for probiotic bacteria: ensuring microbial stability of fish fillets using characterized probiotic bacteria-loaded nanofibers. Innov Food Sci Emerg. 2018. https://doi.org/10.1016/j.ifset.2018. 07.002 .

6. Chan JFW, Yuan S, Kok KH, To KKW, Chu H, Yang J, et al. A familial cluster of pneumonia associated with the 2019 novel coronavirus indicating person-to-person transmission: a study of a family cluster. The Lancet. 2020. https://doi.org/10.1016/s01406736(20)30154-9.

7. Chen Y, Liu Q, Guo D. Emerging coronaviruses: genome structure, replication, and pathogenesis. J Med Virol. 2020. https://doi.org/10.1002/jmv.25681.

8. Chhikara BS, Rathi B, Singh J, Poonam FNU. Corona virus SARS-CoV-2 disease COVID-19: infection, prevention and clinical advances of the prospective chemical drug therapeutics. Chem Biol Let. 2020; http://pubs.iscience.in/journal/index.php/ cbl/article/view/995.

9. Choffnes ER, Relman DA, Olsen LA, Hutton R, Mack A. Improving food safety through a one health approach: workshop summary. Washington, DC: The National Academic Press; 2012. p. $115-30$.

10. Cui J, Li F, Shi ZL. Origin and evolution of pathogenic coronaviruses. Nat Rev Microbiol. 2019. https://doi.org/10.1038/ s41579-018-0118-9.

11. Dhama K, Sharun K, Tiwari R, Sircar S, Bhat S, Malik YS, et al. Coronavirus Disease 2019: COVID-19. Preprints. 2020; https:// doi.org/10.20944/preprints202003.0001.v1.

12. European Commission. Directorate-General for Health and Food Safety. COVID-19 and Food Safety. 2020. https://ec.europa.eu/ food/sites/food/files/safety/docs/biosafety_crisis_covid19_qandas_ en.pdf. Accessed 23 May 2020.

13. Food and Drug Administration. Coronavirus disease 2019 (COVID-19) frequently asked questions. 2020. https://www.fda. gov/emergency-preparedness-and-response/mcm-issues/corona virus-disease-2019-covid-19-frequently-asked-questions. Accessed 13 March 2020.

14. Galanakis CM. The Food Systems in the Era of the Coronavirus (COVID-19) Pandemic Crisis. Foods. 2020; https://doi.org/10. 3390/foods9040523.

15. Galmés S, Serra F, Palou A. Vitamin E metabolic effects and genetic variants: a challenge for precision nutrition in obesity and associated disturbances. Nutrients. 2018. https://doi.org/10.3390/ nu10121919.

16. Grant WB, Giovannucci E. The possible roles of solar ultraviolet$B$ radiation and vitamin $D$ in reducing case-fatality rates from the 1918-1919 influenza pandemic in the United States. DermatoEndocrinology. 2009. https://doi.org/10.4161/derm.1.4.9063.

17. Guan Y, Zheng BJ, He YQ, Liu XL, Zhuang ZX, Cheung CL, et al. Isolation and characterization of viruses related to the SARS coronavirus from animals in southern China. Science. 2003. https://doi.org/10.1126/science.1087139.

18. Harthill M. Micronutrient selenium deficiency influences evolution of some viral infectious diseases. Biol Trace Elem Res. 2011. https://doi.org/10.1007/s12011-011-8977-1.

19. Hemilä H. Vitamin $C$ intake and susceptibility to the common cold. Brit J Nutr. 1997;77(1):59-72.

20. Hemilä H. Vitamin $C$ and SARS coronavirus. J Antimicrob Chemoth. 2003. https://doi.org/10.1093/jac/dkh002.

21. Holmes KV, Lai MMC. Coronaviridae: the viruses and their replication. Fields Vir. 1996;3:1075-93.

22. Hui DS, Azhar IE, Madani TA, Ntoumi F, Kock R, Dar O, et al. The continuing 2019-nCoV epidemic threat of novel coronaviruses to global health-The latest 2019 novel coronavirus outbreak in Wuhan, China. Int J Infect Dis. 2020. https://doi.org/ 10.1016/j.ijid.2020.01.009.

23. Jalava K. First respiratory transmitted food borne outbreak? Int J Hyg Environ Health. 2020. https://doi.org/10.1016/j.ijheh.2020. 113490.

24. Jean J, Morales-Rayas R, Anoman MN, Lamhoujeb S. Inactivation of hepatitis A virus and norovirus surrogate in suspension and on food-contact surfaces using pulsed UV light (pulsed light inactivation of food-borne viruses). Food Microbiol. 2011;28(3):568-72.

25. Jo S, Kim H, Kim S, Shin DH, Kim MS. Characteristics of flavonoids as potent MERS-CoV 3C-like protease inhibitors. Chem Biol Drug Des. 2019. https://doi.org/10.1111/cbdd.13604.

26. Koonin EV, Senkevich TG, Dolja VV. The ancient Virus World and evolution of cells. Biol Direct. 2006. https://doi.org/10.1186/ 1745-6150-1-29. 
27. Le Guyader FS, Le Saux JC, Ambert-Balay K, Krol J, Serais O, Parnaudeau Giraudon H, et al. Aichi virus, norovirus, astrovirus, enterovirus, and rotavirus involved in clinical cases from a French oyster-related gastroenteritis outbreak. J Clin Microbiol. 2008. https://doi.org/10.1128/JCM.01044-08.

28. Li X, Song Y, Wong G, Cui J. Bat origin of a new human coronavirus: there and back again. Sci China Life Sci. 2020; https://doi.org/10.1007/s11427-020-1645-7.

29. Liang W, Guan W, Chen R, Wang W, Li J, Xu K, et al. Cancer patients in SARS-CoV-2 infection: a nationwide analysis in China. Lancet Oncol. 2020. https://doi.org/10.1016/S14702045(20)30096-6.

30. Martina BE, Haagmans BL, Kuiken T, Fouchier RA, Rimmelzwaan GF, Van Amerongen G, et al. SARS virus infection of cats and ferrets. Nature. 2003. https://doi.org/10.1038/425915a.

31. Martineau AR, Jolliffe DA, Hooper RL, Greenberg L, Aloia JF, Bergman P, et al. Vitamin D supplementation to prevent acute respiratory tract infections: systematic review and meta-analysis of individual participant data. BMJ. 2017. https://doi.org/10. 1136/bmj.i6583.

32. Meral R, Ceylan Z, Kose S. Limitation of microbial spoilage of rainbow trout fillets using characterized thyme oil antibacterial nanoemulsions. J Food Saf. 2019. https://doi.org/10.1111/jfs. 12644.

33. Monchatre-Leroy E, Boué F, Boucher JM, Renault C, Moutou F, $\mathrm{Ar}$ Gouilh $\mathrm{M}$, et al. Identification of alpha and beta coronavirus in wildlife species in France: bats, rodents, rabbits, and hedgehogs. Viruses. 2017. https://doi.org/10.3390/v9120364.

34. Mongelli L, Golding B. New York hospitals treating coronavirus patients with vitamin C. 2020. https://nypost.com/2020/03/24/newyork-hospitals-treating-coronavirus-patients-with-vitamin-c/.

35. Munster VJ, Koopmans M, van Doremalen N, van Riel D, de Wit E. A novel coronavirus emerging in China-key questions for impact assessment. N Engl J Med. 2020. https://doi.org/10.1056/ NEJMp2000929.

36. Nonnecke BJ, McGill JL, Ridpath JF, Sacco RE, Lippolis JD, Reinhardt TA. Acute phase response elicited by experimental bovine diarrhea virus (BVDV) infection is associated with decreased vitamin $\mathrm{D}$ and $\mathrm{E}$ status of vitamin-replete preruminant calves. J Dairy Sci. 2014. https://doi.org/10.3168/jds.2014-8293.

37. Pradesh U, Upadhayay PDD, Vigyan PC. Coronavirus infection in equines: a review. Asian J Anim Vet Adv. 2014. https://doi. org/10.3923/ajava.2014/164.176.

38. Rodriguez-Morales AJ, Bonilla-Aldana DK, Balbin-Ramon GJ, Rabaan AA, Sah R, Paniz-Mondolfi A, et al. History is repeating itself: probable zoonotic spillover as the cause of the 2019 novel Coronavirus Epidemic. Infez Med. 2020;28(1):3-5.

39. Rodriguez-Morales AJ, Bonilla-Aldana DK, Tiwari R, Sah R, Rabaan AA, Dhama K. COVID-19, an emerging coronavirus infection: current scenario and recent developments: an overview. J Pure Appl Microbiol. 2020;14:6150.

40. Saul AW. Nutritional treatment of coronavirus. Orthomolecular Medicine News Service. 2020;16:6. https://drlauda.at/images/pdf/ omns/Nutritional_Treatment_of_Coronavirus.pdf. Accessed 29 March 2020.

41. Saul AW. Vitamin C protects against coronavirus. Orthomolecular medicine news service. 2020. https://drlauda.at/images/pdf/ omns/Vitamin_C_Protects_Against_Coronavirus.pdf. Accessed 29 March 2020.

42. Shimizu JF, Lima CS, Pereira CM, Bittar C, Batista MN, Nazaré $\mathrm{AC}$, et al. Flavonoids from Pterogyne nitens inhibit hepatitis $\mathrm{C}$ virus entry. Sci Rep. 2017. https://doi.org/10.1038/s41598-01716336-y.

43. Snijder EJ, Bredenbeek PJ, Dobbe JC, Thiel V, Ziebuhr J, Poon $\mathrm{LL}$, et al. Unique and conserved features of genome and proteome of SARS-coronavirus, an early split-off from the coronavirus group 2 lineage. J Mol Biol. 2003. https://doi.org/10. 1016/S0022-2836(03)00865-9.

44. Stals A, Baert L, Van Coillie E, Uyttendaele M. Extraction of food-borne viruses from food samples: a review. Int $\mathrm{J}$ Food Microbiol. 2012. https://doi.org/10.1016/j.ijfoodmicro.2011.10. 014.

45. Su Z, Wu Y. A multiscale and comparative model for receptor binding of 2019 novel coronavirus and the implication of its life cycle in host cells. BioRxiv. 2020. https://doi.org/10.1101/2020. 02.20.958272.

46. Tatlisu NB, Yilmaz MT, Arici M. Fabrication and characterization of thymol-loaded nanofiber mats as a novel antimould surface material for coating cheese surface. Food Packag Shelf Life. 2019. https://doi.org/10.1016/j.fpsl.2019.100347.

47. Te Velthuis AJ, van den Worm SH, Sims AC, Baric RS, Snijder EJ, van Hemert MJ. Zn2 + inhibits coronavirus and arterivirus RNA polymerase activity in vitro and zinc ionophores block the replication of these viruses in cell culture. PLoS Pathog. 2010. https://doi.org/10.1371/journal.ppat.1001176.

48. van der Hoek L, Pyrc K, Jebbink MF, Vermeulen-Oost W, Berkhout RJ, Wolthers KC, et al. Identification of a new human coronavirus. Nat Med. 2004. https://doi.org/10.1038/nm1024.

49. Velebit B, Djordjevic V, Milojevic L, Babic M, Grkovic N, Jankovic $\mathrm{V}$, et al. The common foodborne viruses: a review. Earth Env Sci. 2019; IOP Publishing. https://doi.org/10.1088/ 1755-1315/333/1/012110.

50. Velebit B, Radin D, Teodorovic V. Transmission of common foodborne viruses by meat products. Proc Food Sci. 2015. https:// doi.org/10.1016/j.profoo.2015.09.069.

51. Wang J, Tang K, Feng K, Lv W. High Temperature and High Humidity Reduce the Transmission of COVID-19. Available at SSRN 3551767. 2020; https://doi.org/10.2139/ssrn.3551767.

52. Wang LF, Shi Z, Zhang S, Field H, Daszak P, Eaton BT. Review of bats and SARS. Emerg Infect Dis. 2006; https://doi.org/10. 3201/eid1212.060401.

53. Wang LS, Wang YR, Ye DW, Liu QQ. A review of the 2019 Novel Coronavirus (COVID-19) based on current evidence. Int J Antimicrob Ag. 2020. https://doi.org/10.1016/j.ijantimicag.2020. 105948.

54. Woodward A. Experts think bats are the source of the Wuhan coronavirus. At least 4 pandemics have originated in these animals. 2020. https://www.businessinsider.com/wuhan-cor onavirus-sars-bats-animals-to-humans-2020-1. Accessed 9 April 2020.

55. World Health Organization (WHO). 2019-nCoV situation reports. $2020 . \quad$ https://www.who.int/emergencies/diseases/novel-cor onavirus-2019/situation-reports. Accessed 10 Feb 2020.

56. World Health Organization (WHO). Coronavirus disease (COVID-19) advice for the public. 2020. https://www.who.int/ emergencies/diseases/novel-coronavirus-2019/advice-for-public. Accessed 10 Feb 2020

57. World Health Organization (WHO). Coronavirus disease (COVID-19) outbreak situation. 2020. https://www.who.int/ emergencies/diseases/novel-coronavirus-2019. Accessed 25 May 2020.

58. World Health Organization (WHO). Disease outbreaks. 2020. https://www.who.int/emergencies/diseases/en/. Accessed 21 March 2020.

59. World Health Organization (WHO). Technical interim guidance for novel coronavirus. 2020. https://www.who.int/health-topics/ coronavirus. Accessed 29 Jan 2020.

60. World Health Organization and Food and Agriculture Organization of the United Nations. COVID-19 and food safety: guidance for food businesses. 2020. WHO/2019-nCoV/Food_Safety/ 2020.1. Accessed 25 May 2020. 
61. Yin Y, Wunderink RG. MERS, SARS and other coronaviruses as causes of pneumonia. Respirology. 2018. https://doi.org/10.1111/ resp.13196.

62. Yu WB, Tang GD, Zhang L, Corlett RT. Decoding the evolution and transmissions of the novel pneumonia coronavirus (SARSCoV-2/HCoV-19) using whole genomic data. Zool Res. 2020; https://doi.org/10.24272/j.issn.2095-8137.2020.022.

63. Yuan J, Lu Y, Cao X, Cui H. Regulating wildlife conservation and food safety to prevent human exposure to novel virus. Ecosyst Health Sust. 2020. https://doi.org/10.1080/20964129.2020. 1741325.

64. Zhang L, Liu Y. Potential interventions for novel coronavirus in China: a systematic review. J Med Virol. 2020. https://doi.org/10. 1002/jmv.25707.
65. Zhou P, Yang XL, Wang XG, Hu B, Zhang L, Zhang W, et al. A pneumonia outbreak associated with a new coronavirus of probable bat origin. Nature. 2020. https://doi.org/10.1038/s41586020-2012-7.

66. Zhu N, Zhang D, Wang W, Li X, Yang B, Song J, et al. A novel coronavirus from patients with pneumonia in China, 2019. N Engl J Med. 2020. https://doi.org/10.1056/NEJMoa2001017.

Publisher's Note Springer Nature remains neutral with regard to jurisdictional claims in published maps and institutional affiliations. 